Ege Tıp Dergisi / Ege Journal of Medicine 2020; 59 (3): 149-154

\title{
IR spektroskopi kullanılarak in vitro meme kanser kök hücrelerinin araştırılması
}

Investigation of breast cancer stem cells in vitro by using IR spectroscopy

\author{
Günnur Güler ${ }^{1}$ Ümmü Güven ${ }^{2}$ Eda Açıkgöz ${ }^{3}$ Gülperi Öktem ${ }^{2-4}$ \\ ${ }_{1}^{1}$ Biyomedikal Mühendisliği, Mühendislik Fakültesi, İzmir Ekonomi Üniversitesi, İzmir, Türkiye \\ ${ }^{2}$ Kök Hücre Anabilim Dalı, Ege Üniversitesi Sağlık Bilimler Enstitüsü, İzmir, Türkiye \\ ${ }^{3}$ Van Yüzüncü Yıl Üniversitesi, Histoloji ve Embriyoloji Anabilim Dalı, Van, Türkiye \\ ${ }^{4}$ Ege Üniversitesi Tıp Fakültesi, Histoloji ve Embriyoloji Anabilim Dalı, İzmir, Türkiye
}

\section{Öz}

Amaç: Kanser kök hücreleri $(K K H)$, tümör içinde kendi kendilerini yenileme ve diğer hücre tiplerine farklılaşabilme kapasitesi sebebiyle tümörün başlaması, ilerlemesi, nüksetmesi, metastaz ve terapötik dirence yol açmaktadır. Bu nedenle, meme kanser kök hücrelerinin (MKKH) karakteristik özelliklerinin belirlenmesi gerekmektedir. Bu çalışmanın amacı, MKKH'lerin akış sitometrisi ile izole edildikten sonra Fourier dönüşümlü kızılötesi (FTIR) spektroskopisi kullanarak hücre biyokimyasındaki farklılaşmalarının moleküler seviyede araştırılmasıdır.

Gereç ve Yöntem: MCF-7 meme kanser hücre hattındaki CD44+/CD24- yüzey belirteç özelliği gösteren MKKH'ler akış sitometrisi ile izole edilmiştir. MCF10A, MCF-7 kanser hücre $(\mathrm{KH})$ hattı ve bu hattan izole edilen CD44+/CD24- yüzey belirteç özelliklerine sahip MKKH'ler \%0,9 $\mathrm{NaCl}$ içerisine resuspanse edildikten sonra FTIR spektrometre ile ölçülmüştür.

Bulgular: MCF-7 içerisindeki CD44+/CD24- yüzey belirteç özelliğine sahip KKH'lerinin sort oranı $\% 2,0-2,3$ olarak belirlenmiştir. Elde edilen FTIR spektrumlarında, $\mathrm{MKKH}$, meme kanser hücreleri $(\mathrm{KH}$, non-KKH, bulk populasyon) ve sağlıklı hücreler arasında spektral benzerlikler ve farklılıklar tespit edilmiştir. MKKH'lerde lipit ve protein sinyalleri daha güçlü olup hücre zarı akışkanlığı ve dinamiği fazladır. Sağlıklı hücreler ile kıyaslandığında, KH'lerde a-helikal proteinler ve DNA sinyallerinde azalmaya karşın negatif yüklü karboksil gruplarından kaynaklanan sinyallerde artış gözlenmektedir. Bu veriler, MKKH'lerin, sağlıklı ve KH'lere kıyasla yapı, içerik ve dinamiği bakımından oldukça farklı bir profil sergilediğini göstermektedir.

Sonuç: Bu çalışma, MKKH'lerinin moleküler yapısı ve içeriğindeki değişikliklerin incelemesi vasıtasıyla terapötik hedefli ilaç çalışmaları yapılabileceğini ortaya koymaktadır. FTIR spektroskopisi boyar madde gerektirmeden, hassas ve hızlı ölçüm alınması, örnek hazırlamada kolaylık ve az miktarda örnek gerektirmesi sebebiyle ileri hücre çalışmalarında ve medikal alanda biyolojik örneklerin analizlerinde kullanılabileceği de gösterilmiştir.

Anahtar Sözcükler: Meme kanseri, kanser kök hücresi, FTIR spektroskopisi, hücre zarı akışkanlığı.

\begin{abstract}
Aim: Cancer stem cells (CSCS) lead to tumor initiation, progression, relapse, metastasis and therapeutic resistance due to the ability of tumor to self-renewal and differentiate into other cell types. Therefore, the characteristic features of breast CSCs need to be determined in detail. The aim of this study was to investigate the differences in cell biochemistry at the molecular level by using Fourier transform infrared (FTIR) spectroscopy after breast CSCs were isolated with flow cytometry.
\end{abstract}

\footnotetext{
Sorumlu yazar: Günnur Güler

Biyomedikal Mühendisliği, Mühendislik Fakültesi, İzmir

Ekonomi Üniversitesi, İzmir, Türkiye

E-posta: gunnurgorucu@gmail.com

Başvuru tarihi: 04.09.2019

Kabul tarihi: 02.11.2019
} 
Materials and Methods: Breast CSCs with CD44+/CD24- surface marker properties in the MCF-7 cancer cell lines were isolated by using flow cytometry (FACS). MCF10A, MCF-7 breast cancer cell line (cancer non-stem cells or non-CSCs) and breast CSCs were re-suspended into $0.9 \% \mathrm{NaCl}$, and each cell type was measured with the FTIR spectrometer.

Results: The portion of breast CSCs with CD44+/CD24- surface marker properties in MCF-7 was 2.02.3\%. In the FTIR spectra, spectral similarities and differences among breast CSCs, non-CSCs and healthy cells were determined. In breast CSCs, the lipid and protein signals are quite strong accompanied with an increased cell membrane fluidity and dynamics. When non-CSCs are compared with healthy cells, a less amount of both $\alpha$-helical proteins and DNA is detected while an increase in the signals of negatively charged carboxyl groups is noticed. These data clearly show that breast CSCs exhibit a very different profile in terms of structure, content and dynamics of cellular macromolecules compared to both non-CSCs and healthy cells.

Conclusion: Drug studies (targeted therapy, drug-action mechanism) can be performed by examining small changes in the molecular structure and content of breast CSCs. This study shows that FTIR spectroscopy can be used in advanced cell studies as well as in the analysis of biological samples in medical field due to rapid, label-free and accurate measurement without complex sample preparation procedures.

Keywords: Breast cancer, cancer stem cell, FTIR spectroscopy, cell membrane fluidity.

\section{Giriş}

Uluslararası Kanser Araştırmaları Ajansı (GLOBOCAN) tarafından 2018 yılında yayınlanan kanserle ilgili istatistikler ile kadınlarda meme kanserinin oldukça yaygın olduğu ve kansere bağlı ölüm nedenleri arasında oldukça önemli bir yere sahip olduğu rapor edilmiştir (1). Tanı ve tedavideki son gelişmelere rağmen, hastalığın mortalitesinin 2020 yılına kadar \%20 oranında artması beklenmektedir $(1,2)$. Nüks etme, metastaz ve tedaviye direnç kanser tedavisindeki başarısızığın en önemli nedenleri arasındadır.

Kanser kök hücreleri $(\mathrm{KKH})$, tümör içinde kendi kendilerini yenileme (self-renewal) ve diğer hücre tiplerine farklılaşabilme kapasitesi yüksek olan küçük bir alt popülasyonunu oluşturmaktadır (3). Meme tümörlerinde, kök hücre özelliklerini gösteren küçük hücre popülasyonu meme kanser kök hücreleri (MKKH) olarak bilinmektedir. MKKH'ler tümörün başlaması, ilerlemesi, nüks ve metastazından sorumludur $(3,4)$. MKKH'ler yüksek ALDH aktivitesinin yanı sıra, CD44+/CD24- fenotipik özellikleri ile karakterizedir. CD44+/CD24- özelliğe sahip popülasyonun daha tümörojenik olduğu ve normal kök hücrelere benzer özellikler sergilediği gösterilmiştir (5).

Vücuttaki hücre tipleri kendi iç dinamikleri veya çevresel faktörlerin etkisi ile farklı davranış paternleri sergilemektedir. $\mathrm{Bu}$ durum büyük oranda hücresel makromoleküllerin değişimleri ile ilişkilendirilmektedir. Normal hücreler veya dokular kanserleşme sürecine girdiğinde makromoleküllerin içeriği ve yapısal konformasyonu büyük oranlarda değişime uğramaktadır $(6,7)$. Bu değişimlerin ortaya çıkarııması hastalığın erken tanı ve tedavisinde önemli avantajlar sağlamaktadır.

Bir titreşim spektroskopisi olan Fourier dönüşümlü kızılötesi (FTIR) spektroskopisi moleküllerin fonksiyonel grupları ile molekül içi/moleküller arası bağlar hakkında doğrudan bilgi sağlamaktadır. IR spektroskopi doku, hücre ve diğer biyolojik örneklerin araştırmalarında yaygın olarak kullanılan biyofiziksel tekniklerden biridir (8-16). Bu çalışmamızda, MCF-7 meme kanser hücre hattındaki CD44+/CD24- yüzey belirteç özelliği gösteren MKKH'lerin akış sitometrisi ile izole edildikten sonra FTIR spektroskopisi ile hücre biyokimyasındaki farklılaşmalarının ortaya çıkarılması ve moleküler mekanizmanın aydınlatılması amaçlanmıştır.

\section{Gereç ve Yöntem}

\section{Hücre kültürü}

Amerikan Tip Kültür Koleksiyonundan (ATCC) temin edilen MCF10A sağlıklı meme epitel hücreleri ve MCF-7 insan meme kanser hücre hattı kullanılmıştır. MCF10A hücreleri $25 \mathrm{~cm}^{2}$ lik steril filtreli flask içerisinde $\% 5$ at serum, epitelyal büyüme faktörü (EGF) $(20 \mathrm{ng} / \mathrm{ml})$, insülin (10 $\mu \mathrm{g} / \mathrm{ml})$, hidrokortizon $(0,5 \mathrm{mg} / \mathrm{ml})$, kolera toksini $(100 \mathrm{ng} / \mathrm{ml})$ ve penisilin/streptomisin $(100 \mu \mathrm{g} / \mathrm{ml})$ bulunan DMEM/F12 besi ortamı içerisinde çoğaltılmıştır. MCF-7 hücre hattının üretilmesi ve çoğaltılması amacıyla içerisinde $\% 10$ oranında eklenmiş Isı ile inaktive edilmiş fetal bovin serumu ile penisilin/streptomisin $(100 \mu \mathrm{g} / \mathrm{ml})$ 
bulunan RPMI-1640 besi ortamı kullanılmıştır. Hücreler $37^{\circ} \mathrm{C}$ 'de, \%5 $\mathrm{CO}_{2}$ ve nem içeren inkübatörde çoğaltılmıştır. Hücrelerin genel durumları "inverted" mikroskopta izlenmiştir. Yaklaşık \%80-85'in üzerindeki hücre yoğunluğunda pasajlama işlemi gerçekleştirilmiştir.

\section{CD44+/CD24- MKKH'lerin izolasyonu}

Kanser kök hücre izolasyonunda CD44 ve CD24 hücre yüzey belirteçleri kullanılmıştır. MCF-7 hücre hattındaki CD44+/CD24- fenotip özelliğine sahip olan hücre popülasyonu floresan aktif hücre ayırma (FACS) ile izole edilmiştir. Tripsin ile flask yüzeyinden kaldırılan hücreler içerisinde $\% 0,5$ bovin serum albümin bulunan fosfat tamponu ile yıkanmıştır. Hücreler $\left(1 \times 10^{5}\right.$ hücre/ml) 10'ar $\mu \mathrm{l}$ FITC işaretli CD44 ve $\mathrm{PE}$ işaretli CD24 antikorlar ile karanlık ortamda $+4^{\circ} \mathrm{C}$ 'de 10 dakika inkübe edilmiştir. Sonrasında, hücreler FACS tamponu ile üç defa yıkanarak FACS Aria akış sitometrisi (BD Biosciences, USA) kullanılarak CD44+/CD24- özelliğine sahip olan hücrelerin ayırımı yapılmıştır.

\section{Hücre örneklerinin FTIR için hazırlanması}

MCF10A, MCF-7 hücre hattı ve bu hattan izole edilen CD44+/CD24- hücreleri ortamdaki hücresel atıkların uzaklaştııılması amacıyla $\left(1 \times 10^{6}\right.$ hücre $\left./ \mathrm{ml}\right) \% 0,9 \mathrm{NaCl}$ içerisinde üç defa yıkanmıştır. Hücreler 1000 rpm'de 5 dakika santrifüj edildikten sonra izotonik solüsyon içerisinde yeniden çözdürülmüştür.

\section{ATR-FTIR ölçümleri}

MCF-7 kanser hücresi (insan meme adenokarsinoma hücre) ve MCF10A sağlıklı hücre (insan meme tümörojenik olmayan epitel hücre) hattı kullanılmıştır. MCF-7 akış sitometrisi ile ayırt edildikten sonra hücre alt-popülasyonları (MKKH, KH), DLATGS detektörü ile donatılmış ve zayıflatılmış toplam yansıma (ATR) ünitesine sahip IRTracer-100 FTIR spektrometresi (Shimadzu, Japonya) ile ölçülmüştür. Hücre süspansiyonunun 1,8 $\mu$ l'si ( $1 \times 10^{6}$ hücre/ml) ATR kristali üzerinde $\sim 12$ dakika kurutulmaya bırakıımıştır. Bağımsız olarak yetiştirilen her bir kültürden alınan üç numune farklı zamanlarda üçer kez kaydedilerek FTIR ölçümleri üç kopya halinde gerçekleştirilmiştir. Her interferogram için $4 \mathrm{~cm}^{-1}$ spektral çözünürlükte toplam 128 tarama ortalaması alınmıştır. Arka plan spektrumu olarak ATR kristali boş olduğunda hava spektrumu kaydedilmiştir $(8,10,17)$.

\section{FTIR veri analizleri}

Hücre örneklerinin spektrumları spektrometre yazılım programı LabSolutions (Shimadzu, Japonya) ile kaydedildikten sonra, spektral önişlem, ikinci derece türev spektrumları, fark spektrumları ve Student t-testleri MATLAB altında çalışan 'Kinetics' yazılımı ile gerçekleştirilmiştir (8, 10, 17). Öncelikle, 1562-1555 $\mathrm{cm}^{-1}$ bandı referans alınarak hücre spektrumundaki atmosferik su buharı sinyalleri çıkarılmıştır. Tüm spektrum üzerinde "baseline düzeltmesi" yapıldıktan sonra $1585-1483 \mathrm{~cm}^{-1}$ bandı eşit alan için normalize edilmiştir. Her bir hücre örneği için ön işlem görmüş (baseline düzeltilmiş ve normalize edilmiş) absorbans spektrumlarının (en az 15 spektrum) ortalaması alınmıştır.

\section{Bulgular}

\section{CD44+/CD24- meme KKH'lerinin izolasyonu}

Kanser kök hücreleri spesifik hücre yüzey belirteçlerine göre izole edilmektedir. Çalışmamızda, MCF-7 meme kanser hücre hattı içerisindeki CD44+/CD24- yüzey özelliklerine sahip olan hücreler akış sitometrisi kullanılarak izole edilmiştir (Şekil-1). CD44+/CD24- "sort" oranları \%2,0-2,3 arasında değişirken, bunun dışında kalan hücre popülasyon (bulk popülasyon) oranları \%97,7-98 arasındadır. İşlem sonrasında, elde edilen hücrelerin saflık düzeylerin akış sitometrisi ile kontrol edilmiş olup "sort" işleminden sonra saflık oranları>90'dır.
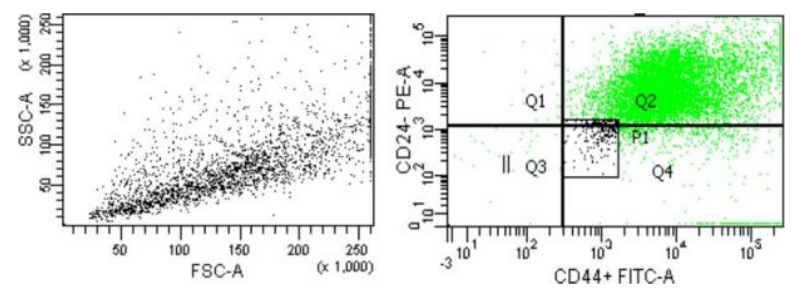

Şekil-1. Meme kanser hücre hattı (MCF-7) içerisindeki CD44+/CD24- özelliğine sahip MKKH popülasyonunun akış sitometrisi ile izolasyonu.

\section{ATR-FTIR sonuçları}

Kanser kök hücrelerinin, kök hücre olmayan meme kanser hücrelerinin $(\mathrm{KH})$ ve sağlıklı meme hücrelerinin tüm spektrumları Şekil-2A'da gösterilmiştir. Bu grafikten elde edilen FTIRortalama absorbans spektrumları her bir hücre örneği (MKKH, KH, sağlıklı) için Şekil-2B'de verilmiştir. Hücresel makromoleküllerin fonksiyonel grupların bağ titreşimlerine karşılık gelen güçlü IR sinyalleri grafikte $3015-2800$ ve 
$1800-800 \mathrm{~cm}^{-1}$ spektral aralığında gösterilmiş olup; $3015-2800 \mathrm{~cm}^{-1}$ aralığında lipit (çoğunlukla) ve proteinlerin $\mathrm{CH}_{2} / \mathrm{CH}_{3}$ yapıları, $1720-1760 \mathrm{~cm}^{-}$ ${ }^{1}$,de lipit ester $\mathrm{C}=\mathrm{O}$ yapıları, $1700-1600 \mathrm{~cm}^{-1}$, de protein $\mathrm{C}=\mathrm{O}$ yapıları (Amid I), $1250-1190 \mathrm{~cm}^{-1} \mathrm{de}$ $\mathrm{PO}_{2}$ yapıları (nükleik asitler, fosfolipitler), 1190$800 \mathrm{~cm}^{-1}$ aralığında ise şeker gruplarının (glikojen, oligosakkaritler) $\mathrm{COH}$ ve $\mathrm{CC}$ yapıları görülmektedir.
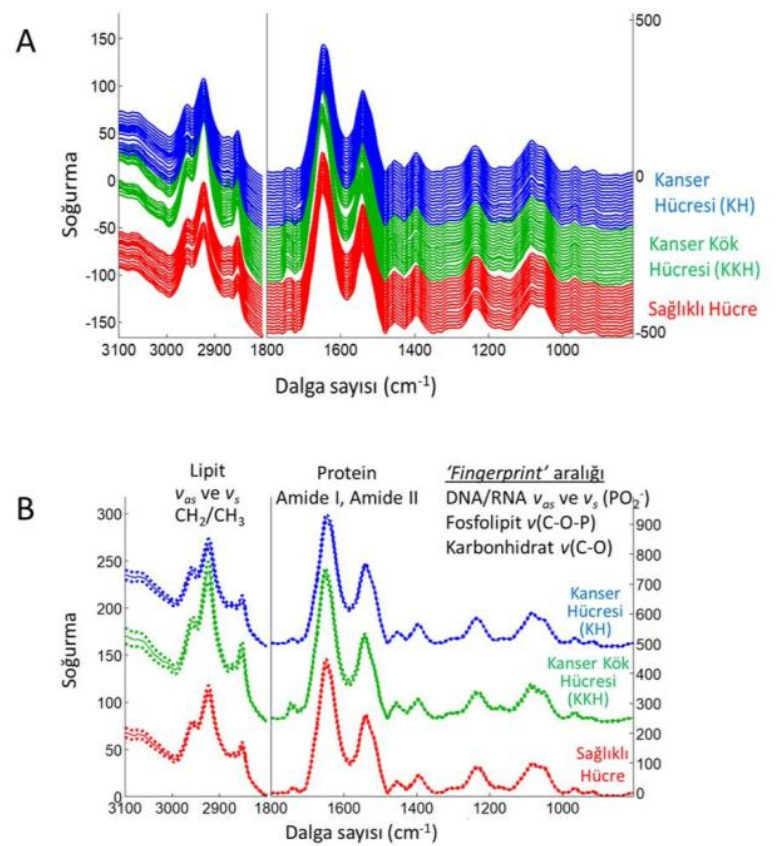

Şekil-2. MKKH'lerin, kök hücre olmayan meme kanser hücrelerinin $(\mathrm{KH})$ ve meme sağlıklı hücrelerin (A) absorbans FTIR spektrumları (3015-2800 ve $1800-800 \mathrm{~cm}^{-1}$ spektral aralığında). (B) $\mathrm{KKH}, \quad \mathrm{KH}$ ve sağlıklı hücrelerin $(\mathrm{A})^{\prime}$ 'dan hesaplanan ortalama absorbans spektrumları ve Student t-testi (her dalga boyunda $\alpha=\% 0,1^{\prime}$ lik anlamlılık seviyesine sahip). Spektrum üzerindeki noktalar istatistiksel olarak anlamlı farkları ifade eder. Daha iyi okunabilirlik için spektrumlar absorbans skalasında dengelenmiştir (rescaled).

Meme kanser kök hücreleri, $\mathrm{KH}$ ve sağlıklı hücreler arasında spektral benzerlikler ve farklılıklar görülmektedir (Şekil-2B). Bu farklılaşmalar lipit bölgesinde $\left(3000-2800 \mathrm{~cm}^{-1}\right)$ daha belirgin olup, MKKH'ye ait lipit sinyalleri diğer hücrelere göre daha güçlüdür. Protein ve 'fingerprint' bölgelerindeki küçük farklılıkları tespit edebilmek amacıyla FTIR-fark spektrumuna intiyaç vardır (17). FTIR-fark spektrumları, farklı hücre tipleri ve alt popülasyonları için ortalama absorbans spektrumlarının birbirinden matematiksel olarak çıkartılmasıyla elde edilmiş olup (MKKH)-(KH), (MKKH)-(Sağlıklı hücre) ve
(KH)-(Sağlıklı hücre) şeklinde gösterilmiştir (Şekil-3). (MKKH)-(KH) fark spektrumunda, KH'lere kıyasla MKKH'lerde lipit, protein, nükleik asit ve karbonhidrat yapılarından kaynaklanan 3015-2800, 1743, 1657, 1548, 1223, 1178, 1140, 1090 ve $1040 \mathrm{~cm}^{-1}$,de pozitif pikler dikkat çekmektedir (Şekil-3a). IR sinyallerin pozitif yönde artış göstermesi biyomoleküllerin miktarı ile doğrudan ilişkilidir. (MKKH)-(Sağlıklı hücre) fark spektrumunda yine MKKH'lerde benzer biyomoleküllerinin IR sinyallerinde artış gözlenmektedir (Şekil-3b). KH'ler ve sağlıklı hücreler karşılaştırıldığında, MKKH'lerde 1000$800 \mathrm{~cm}^{-1}$ aralığında negatif ve pozitif yönlerde küçük spektal farklılaşmalar görülmektedir. Bu bölgedeki IR sinyalleri nükleik asitlerin şekerfosfat omurgasındaki C-C, C-O, O-P-O gerilmelerinden kaynaklanmaktadır. MKKH'lerde $3010 \mathrm{~cm}^{-1}$, de (olefinik, $=\mathrm{CH}$ ) sinyal artışı gözlenmektedir. Ayrıca, MKKH'lerde $1743 \mathrm{~cm}^{-1}$ (lipit ester $\mathrm{C}=\mathrm{O}$ ) ve $1176 \mathrm{~cm}^{-1}$ (trigliserit, kolesterol esterleri) bantlarında eşzamanlı pozitif pikler görülmektedir. (KH)-(Sağlıklı hücre) fark spektrumunda (Şekil-3c), spektral farklılıklar protein $\left(1659,1540 \mathrm{~cm}^{-1}\right.$ ) ve nükleik asitler (1250-1180 cm $\mathrm{cm}^{-1}, 1085-1020 \mathrm{~cm}^{-1}$ : fosfodiester bağ titreşimleri) bölgelerindeki negatif sinyallerden ibarettir. Buna karşın, KH'lerde 1570 ve $1405 \mathrm{~cm}^{-1}$ 'de artış gösteren $\mathrm{COO}^{-}$(negatif yüklü karboksil) gruplardan kaynaklanan pozitif sinyaller gözlenmektedir.

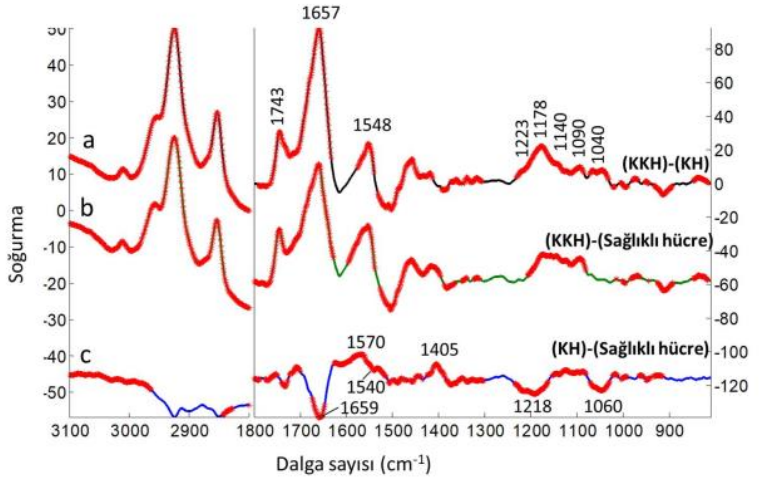

Şekil-3. MKKH'lerin, kök hücre olmayan meme kanser hücrelerinin $(\mathrm{KH})$ ve meme sağlıklı hücrelerin FTIR-fark spektrumları ve Student t-testi. (a) (MKKH)-(KH), (b) (MKKH)-(Sağlıklı hücre) ve (c) (KH)-(Sağlıklı hücre). FTIR-fark spektrumları, ortalama absorbans spektrumlarının birbirinden matematiksel olarak çıkarılmasıyla elde edilmiştir. Student t-testi her dalga boyunda $\alpha=\% 0,1^{\prime}$ lik anlamlılık seviyesine sahiptir. Spektrum üzerindeki kırmızı noktalar istatistiksel olarak anlamlı farklılaşmayı ifade eder. 
FTIR-ikinci derece türev spektrumlarında (Şekil4), $3025-2825 \mathrm{~cm}^{-1}$ spektral aralığında alınan pikler doymuş/doymamış lipitlerden kaynaklanmaktadır. Lipit açil $\mathrm{CH}_{2} / \mathrm{CH}_{3}$ sinyallerinin incelenmesi hücre zarının biyofiziksel özellikleri/dinamiği hakkında doğrudan bilgi vermektedir (10). Olefinik $(=\mathrm{CH})$ doymamış lipitler MKKH'lerde $3010 \mathrm{~cm}^{-1}$, de geniş ve artan bir bant verirken (Şekil-4b), KH ve sağlıklı hücrelerde $3007 \mathrm{~cm}^{-1}$, de pik vermektedir (Şekil-4a ve 4c). KH ve sağlıklı hücrelere karşın, MKKH'lerde $\mathrm{CH}_{2}$ asimetrik ve simetrik gerilme vibrasyonlarından kaynaklanan bant pozisyonları yüksek dalga sayısına (upshifted) kaymaktadır (MKKH için $\mathrm{v}_{\mathrm{as}}\left(\mathrm{CH}_{2}\right): 2921,9 \mathrm{~cm}^{-1} ; \mathrm{v}_{\mathrm{s}}\left(\mathrm{CH}_{2}\right)$ : $2851,8 \mathrm{~cm}^{-1}$ ). Bu durum, MKKH'lerin daha düzensiz lipit yapısına sahip olduğunu, dolayısıyla hücre zarının akışkanlığını/dinamiğini göstermektedir.

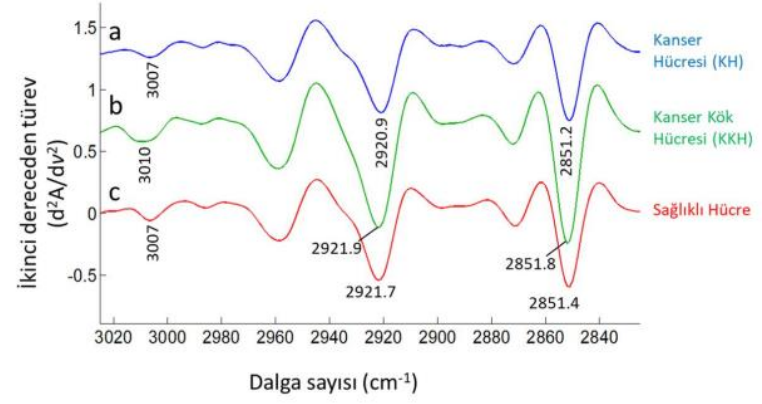

Şekil-4. (a) Meme kanser hücrelerinin $(\mathrm{KH})$, (b) MKKH'lerin ve (c) meme sağlıklı hücrelerinin FTIR ikinci derece türev spektrumları (3025$2825 \mathrm{~cm}^{-1}$ spektral aralığında). İkinci derece türev spektrumları Şekil-3'teki ortalama absorbans spektrumlarından elde edilmiştir.

\section{Tartışma}

Kanser kök hücreleri morfolojik, fonksiyonel ve moleküler açıdan tümör dokusu içerindeki diğer hücrelerden farklı özellikler sergilemektedir. Bu özelliklerin ortaya çıkarılması kanser tanı ve tedavisi için önem arz etmektedir. Kanser kök hücrelerinin hayatta kalma ve yayılmasında avantaj sağlayan moleküler yapı özelliklerini anlamak, potansiyel hedef noktalarının belirlenmesini sağlayacaktır. Çalışmamızda, MKKH'lerin sağlıklı hücrelerden ve tümör dokusu içerisindeki diğer hücre populasyonundan farklı kılan makromolekül profillerinin belirlenmesi amaçlanmaktadır.

Kanser kök hücreleri normal ve farklılaşmış hücrelere kıyasla farklı metabolik profiller sergilemektedir. Proliferasyon kapasitesi oldukça yüksek olan KKH'lerin yaşamlarını sürdürdüğü mikro çevresel koşullar yetersiz kan damarı, hipoksi, asidik ve besin yönünden zayıf ortamlar olarak karakterize edilebilir. $\mathrm{Bu}$ nedenle, KKH'lerin mikro ortamlarda hayatta kalabilmek için hücresel biyoenerjisini etkili bir şekilde adapte etmesi gerekmektedir. Protein, lipit, karbonhidrat yapılarındaki değişim ile karakterize edilen metabolik yeniden düzenleme aynı zamanda hücre sinyal yolak akışını önemli ölçüde etkilemektedir (18).

Lipit sentez, lipit satürasyon düzeyleri ve yağ asidi oksidasyonundaki değişikliklerin tümü $\mathrm{KKH}$ metabolizmasının düzenlemesinde önemli roller oynamaktadır (19-21). Lipit metabolizmasındaki değişiklikler, KKH'lerin sadece enerji intiyacı ve biyokütle üretimini karşılamakla kalmaz aynı zamanda birçok önemli onkogenik sinyal yolunun aktivasyonuna da katkıda bulunmaktadır. Çalışmada elde edilen lipit profilleri MKKH'lerin hem sağlıklı hücre hem de KH'lere kıyasla farklı özelliklere sahip olduğunu göstermiştir. En belirgin farklılıklar doymamış yağ asitlerinde saptanmıştır. KKH'lerinde doymamış yağ asit düzeylerindeki artış birçok biyolojik fonksiyon ile ilişkilendirilebilir. Lipitlerinin doymuşluk düzeyi hücre zarı akışkanlığını etkilemektedir. Hücre zarı mekanik özellikleri hücre bölünmesi, migrasyon, metastaz ve sinyal iletimi için kritiktir $(21,22)$. Yapılan bir çalışmada, hücre zarı akışkanlığının azaltılmasının meme kanserinin metastatik kapasitesini olumsuz yönde etkilediği gösterilmiştir (23).

\section{Sonuç}

$\mathrm{Bu}$ çalışmadan elde ettiğimiz sonuçlar, MKHH'lerin, sağlıklı ve KH'lere kıyasla yapı, içerik ve dinamiği bakımından oldukça farklı özellikler sergilediğini ortaya koymaktadır. Bununla birlikte bu çalışmamız, etiketsiz (labelfree), hızlı ve hassas ölçüm alınması, örnek hazırlama kolaylığı ve az miktarda örnek gerektirmesi sayesinde kanser tanı ve tedavisi amacıyla ileri hücre çalışmalarında ve medikal alanda FTIR tekniğinin kullanılabileceğini göstermektedir.

\section{Teşekkür}

ATR-FTIR spektroskopi ölçümleri, İlaç Geliştirme ve Farmakokinetik Araştırma-Uygulama Merkezi'nde yapılmış olup Prof. Dr. Ercüment Karasulu'ya, ve temin edilen 'Kinetics' yazılımı için Prof. Dr. Erik Goormaghtigh'e teşekkür ediyoruz.

Çıkar çatışması: Yazarlar çıkar çatışması beyan etmemişlerdir. 


\section{Kaynaklar}

1. Bray F, Ferlay J, Soerjomataram I, Siegel RL, Torre LA, Jemal A. Global cancer statistics 2018: GLOBOCAN estimates of incidence and mortality worldwide for 36 cancers in 185 countries. CA Cancer J Clin 2018; 68: 394-424.

2. Siegel RL, Miller KD, Jemal A. Cancer statistics. CA Cancer J Clin 2018; 68: 7-30.

3. Chen K, Huang Y, Chen J. Understanding and targeting cancer stem cells: therapeutic implications and challenges. Acta Pharmacol Sin 2013; 34: 732-40.

4. Palomeras S, Ruiz-Martínez S, Puig T. Targeting Breast Cancer Stem Cells to Overcome Treatment Resistance. Molecules 2018; 23: 2193.

5. Al-Hajj M, Wicha MS, Benito-Hernandez A, Morrison SJ, Clarke MF. Prospective identification of tumorigenic breast cancer cells. Proc Natl Acad Sci 2003; 100: 3983-8.

6. Shetty G, Kendall C, Shepherd N, Stone N, Barr H. Raman spectroscopy: elucidation of biochemical changes in carcinogenesis of oesophagus. Br J Cancer 2006; 94: 1460-4.

7. Kumar S, Desmedt C, Larsimont D, Sotiriou C, Goormaghtigh E. Change in the microenvironment of breast cancer studied by FTIR imaging. Analyst 2013; 138: 4058-65.

8. Güler G, Guven U, Oktem G. Characterization of CD133+/CD44+ human prostate cancer stem cells with ATR-FTIR spectroscopy. Analyst 2019; 144: 2138-49.

9. Ozdil B, Güler G, Acikgoz E, Kocaturk, DC, Aktug H. The effect of extracellular matrix on the differentiation of mouse embryonic stem cells. J Cell Biochem doi: 10.1002/jcb.29159.

10. Güler G, Acikgoz E, Karabay Yavasoglu NÜ, Bakan B, Goormaghtigh E, Aktug H. Deciphering the biochemical similarities and differences among mouse embryonic stem cells, somatic and cancer cells using ATR-FTIR spectroscopy. Analyst 2018; 143: 1624-34.

11. Güler G, Vorob’Ev MM, Vogel V, Mäntele W. Proteolytically-induced changes of secondary structural protein conformation of bovine serum albumin monitored by Fourier transform infrared (FT-IR) and UV-circular dichroism spectroscopy. Spectrochim Acta-Part A Mol Biomol Spectrosc 2016; 161:8-18.

12. Smolina M, Goormaghtigh E. Infrared imaging of MDA-MB-231 breast cancer cell line phenotypes in $2 D$ and 3D cultures. Analyst 2015; 140: 2336-43.

13. Benard A, Desmedt C, Smolina M, et al. Infrared imaging in breast cancer: automated tissue component recognition and spectral characterization of breast cancer cells as well as the tumor microenvironment. Analyst 2014;139:1044-56.

14. Kumar S, Shabi TS, Goormaghtigh E. A FTIR imaging characterization of fibroblasts stimulated by various breast cancer cell lines. PLoS One 2014; 9: e111137.

15. Zhao R, Quaroni L, Casson AG. Fourier transform infrared (FTIR) spectromicroscopic characterization of stem-like cell populations in human esophageal normal and adenocarcinoma cell lines. Analyst 2010; 135: 53-61.

16. Hughes C, Liew M, Sachdeva A, et al. SR-FTIR spectroscopy of renal epithelial carcinoma side population cells displaying stem cell-like characteristics. Analyst 2010; 135: 3133-41.

17. Güler G, Acikgoz E, Öktem G. Determination of cellular differences of CD133+/CD44+ prostate cancer stem cells in two-dimensional and three-dimensional media by Fourier transformation infrared spectroscopy. Dokuz Eylül Üniversitesi Tıp Fakültesi Dergisi 2019; 33: 45-56.

18. Lue H, Podolak J, Kolahi K, et al. Metabolic reprogramming ensures cancer cell survival despite oncogenic signaling blockade. Genes Dev 2017; 31: 2067-84.

19. Kuo CY, Ann DK. When fats commit crimes: fatty acid metabolism, cancer stemness and therapeutic resistance. Cancer Commun 2018; 38: 47.

20. Mukherjee A, Kenny HA, Lengyel E. Unsaturated Fatty Acids Maintain Cancer Cell Stemness. Cell Stem Cell 2017; 20: 291-2.

21. Yi M, Li J, Chen S, Cai J, et al. Emerging role of lipid metabolism alterations in Cancer stem cells. J Exp Clin Cancer Res 2018; 37: 118.

22. Taraboletti G, Perin L, Bottazzi B, Mantovani A, Giavazzi R, Salmona M. Membrane fluidity affects tumor-cell motility, invasion and lung-colonizing potential. Int J Cancer 1989; 44: 707-13.

23. Zhao W, Prijic S, Urban BC, et al. Candidate antimetastasis drugs suppress the metastatic capacity of breast cancer cells by reducing membrane fluidity. Cancer Res 2016; 76: 2037-49. 